\title{
Essay on Indifference: Affect and Thinking From Spinoza to Freud and Deleuze
}

\author{
Szymon Wróbel \\ University of Warsaw, Warsaw, Poland
}

\begin{abstract}
In this paper, the author is questioning the very concept of “indifference of thinking”. The author also asks: In what sense, thinking leads to "overall indifference”? What, indeed, is indifference? Reading carefully, the philosophical texts on affects, mainly Spinoza, Freud, Bergson, and Deleuze, author argues that indifference is not a kind of non-affection, beside-affection, post-affection, but rather, it is a trace of affect-just as cinders are remnants of fire. Indifference is neither abnegation which is a kind of statement that we could not care less. On the contrary, it is in indifference where we find profound commitment to bringing back things of this world to their natural position.
\end{abstract}

Keywords: active state, conatus, contrary affect, death drive, façade formations, general indifference, madness, resolution, sustainability

\section{Introduction (General Indifference)}

Gilles Deleuze, in his book entitled What is Philosophy?, formulates the surprising thesis according to which "[t]hinking provokes general indifference" (Deleuze \& Guattari, 1994, p. 50). Deleuze would not be himself if he did not add straightaway that "[i]t is a dangerous exercise nevertheless" (Deleuze \& Guattari, 1994, p. 50). The association of thought process with indifference is surprising not only because Deleuze has himself evidenced beyond reasonable doubt that his own thinking is far from being indifferent, but also because the Spinozian paradigm makes of an affect the very requirement of thinking, which is obviously at odds with the requirement of thinking in the apparent absence of affect.

Thereby, in this text, the author will question the indifference of thinking. In what sense may thinking produce overall indifference? What, indeed, is indifference? Is indifference a kind of non-affection, beside-affection, post-affection, or rather, it may be conceived as a trace of past affect-just as cinders are remnants of fire? Certainly, indifference in thinking is far from neutrality in politics or impartiality in law. It is biased and it is the core bias of thinking. Similarly, indifference does not strictly follow the logic of bi-negation- "neither this nor that" nor it is akin to apathy-a condition of being free from emotion. Similarly, it is neither abnegation which in itself would have driven us to the preconception that we could not care less. On the contrary, it is in indifference where we find profound commitment to bringing back things of this world to their natural position.

Here, the author will be questioning whether thinking is, in fact, a kind of emergency procedure undertaken in order to extinguish the fire which excites thinking and whether thinking is indeed professed with

Szymon Wróbel, Professor, Institute of Philosophy and Sociology of Polish Academy of Sciences, Faculty of Artes Liberales, University of Warsaw, Warsaw, Poland. 
the help of indifference of concepts. What, speaking of which, do we mean by “indifference of concepts"? Even though we may agree with the idea of "indifference of concepts" we could do the same regarding the idea of indifference. When speaking of indifference, we ought to always refer its subject-the what and the who-and pay attention to how is indifference manifested. Are we willing to accept that indifference of concepts towards affects or indifference of concepts themselves constitute what we may call the expected final condition of thinking? Since thinking, as the author is prone to believe, bears resemblance to a firefighting emergency operation, would it be incorrect to assume that its exercise poses certain dangers? If a philosopher who by profession thinks concepts and as such is a friend of concepts always indifferent in communication, contemplation, and reflection, then would such a condition entail that as such it is the enemy of affect?

\section{Façade Formations (Infiltrations)}

Attempting to answer these questions, let us start off with Freudian psychoanalysis. Freud himself ponders intensely upon the mysterious relationship between affects and concepts. For Freud, analysis is in fact not so much a translation or transcription based on "speculative fiction of nerve cells", but a type of parsing and chemical analysis seeking to break down the imaginary-affective complex. Freud dreams of a complete partition of the dream, and the partition of the pathogenic formation, which he perceives to be a sort of infiltration in the mental apparatus. Solution and resolution [Auflösung und Lösung]—laconically writes Freud-are one and the same.

If you were able to break such a pathological idea down to its component parts, to the state from which they came into mental life of a patient, this would mean that if they fell apart the patient would be liberated from them. (Freud, 1900/1957, p. 54)

Freedom is therefore the release of the excess affective-imaginative formation which is obstructive to thinking, i.e., phantasms, which not only need to be dismantled, but also removed in the process of partition.

In Freud's reasoning, it is important that the pathogenic material is treated as a foreign body in the organism that should be removed from the living tissue. But how to do it? Freud is well aware of the limitations of the metaphor of surgery. Foreign body in the organism is indeed foreign, i.e., it is not connected to the tissue yet it causes its inflammation. In the case of mental formation, such a foreign body cannot be removed from the mental apparatus without first destroying it. Foreign body becomes an inseparable part of the tissue specific to the mental apparatus to such an extent that it becomes the mental apparatus.

The inner layers—writes Freud-increasingly alienate from the "I" (ego, das Ich), even though the limit of what is pathogenic, actually never begins to reveal. Pathogenic organization actually does not behave like a foreign body, instead its behaviour resembles infiltration. As such, in this comparison infiltration should be considered resistance. After all, therapy is not about eradicating anything-psychotherapy cannot make it today-but about melting down resistance and thus paving the way for circulation in previously foreclosed area. (Freud, 1910, p. 223)

Here, we come to the essential issue, i.e., the issue of eliminating the symptom without eliminating the structures of "I" (ego, das Ich); bringing back circulation to where it was already close to arrest. The changes in the metaphor whereby a "foreign body" is replaced with "infiltration" and "elimination" is exchanged for "melting down" are the key here.

Over the years of his career, Freud was—not without much difficulty—struggling to liberate himself from thinking about the therapeutic process in terms of hypnosis. Finally, in the text entitled "On Psychotherapy" 
published in 1905, Freud makes the distinction between analytic method and hypnotic techniques of suggestion. In fact, he does it so vividly, that ever since these two techniques will appear to him not only different but their own opposites. Freud, when formulating this crucial distinction, refers to Leonardo da Vinci's distinction between the two types of arts-per via di porre, or painting, which is realized through filling empty places, and per via di levare, that is sculpture, which is realized through removal of excess material. "Painting-Leonardo says as quoted by Freud-works per via di porre, because the painter puts a speck of paint where there was none before on neutral canvas; sculptor, however, works with per via di levare, because the sculptor carves away the obstructions that hide the true from his statue" (Freud, 1904/1905, p. 245).

Equipped with his analytical method Freud, like a sculptor, carves away the excess material. Josef Breuer, in turn, professes hypnotic method exerting something that he expects to be strong enough to invalidate the very manifestation of the pathogenic formation. In contrast, analytical therapy creates nothing, nor does it introduce anything new; its tenet—says Freud-“is to liquidate, extract, eliminate”. The remaining question, however, is what to liquidate if the pathogenic material, as it was established, is not a foreign body but a dripstone on the texture of "I" proper? Let us ask again: Do we incite fire or extinguish it? Do we excise the foreign body (degeneration) or dissolve it?

What does all this mean in the subject of thinking aimed at complete indifference? For Freud, affects are by no means mindless movements of the soul. Affects act intelligently by creating façade formations, but they also form infiltrations resembling frescoes. The analyst, however, is not a minimalist painter aiming to wipe off these growths, but a sculptor carving away the unnecessary pathogenic formations. Perhaps a doctor-analyst is neither a neurosurgeon (knife), nor a pyrotechnician (fire), nor even a chemist (solvent), but indeed a sculptor seeing through multiple distortions the proper form of the brain. After all, Freud himself says that a forceps delivery leaves baby's skull cast in the shape of the mother's pelvis (Freud, 1915, p. 167).

A doctor exercises thinking and this is what allows him/her to "keep disengaged" rather than engage into a foreplay with the subject comfortably reclining on the couch. This does not mean, however, that a doctor does not feel, on the contrary, a doctor senses to the extent that he/she serves as a sensitive canvas for the patient's unconsciousness. So to speak, a doctor becomes a telephone receiver lacking a microphone. Faded magic is also on the patient's side, who speaks in order to be heard, and therefore to be recognized as a worthy object of love. A patient wants his/her affect to be listened to-this way revealing the desire to be loved. This desire may indeed be heard, or rather listened to, but it is never satisfied.

\section{Man of Thought}

The author would like to confront this Freudian way of thinking about affects with the philosophy of Benedict Spinoza. Gilles Deleuze (1988b) claimed that the Spinozian idea of parallelism not only rejects any causality between mind and body, but that it also excludes any hierarchy between one and the other (p. 30). However, this is not true. Despite the fact that the body exceeds just how we imagine our body and that thinking exceeds our awareness of thinking, it is still the body that serves as the model of every presentation. In humans, it is the body, not the soul that commands both the order of our actions and our cognition. Spinoza explicitly writes that the more capable it is the body in comparison with other bodies in acting and in experiencing, the more capable of learning is the soul in comparison with others (Spinoza, 1677/2002, p. 82).

The primacy of the body in Spinoza's doctrine stems from the proposition XXXIX in the fifth part of the Ethics, stating: "He whose body is capable of the greatest amount of activity has a mind whose greatest part is 
eternal” (Spinoza, 1677/2002, p. 370). In the scholium, Spinoza develops this proposition albeit in other direction. There he writes: "he whose body is capable of very considerable activity has a mind which, considered solely in itself, is highly conscious of itself and of God and of things” (Spinoza, 1677/2002, p. 371). This manifold gift consists in letting the body be taken over by multiple and partial drives yet without resorting to any order. This is perhaps a praise of polymorphous perversity of the body, since the victory in alienating the world would entail the primacy of psychosis, while the victory in suppressing multiple drives would entail the primacy of neurosis.

For Spinoza, the human mind, when considered solely in itself, is only an idea or, otherwise, it is the knowledge of the human body. By no means, it is a kind of self-consciousness or higher consciousness, or yet the knowledge of knowledge, which warrants the knowledge itself. At its best, it is rather "a form of ideas" or a modus of thinking. "If one knows something, therefore, one thus knows that one knows it, and at the same time one knows that one knows, and so on to infinity" (Spinoza, 1677/2002, p. 100). Finally, it is because of the body, and not because of lack of knowledge, imagination, or because of sheer ignorance, that we imagine the sun as being close, i.e., at a distance, no more than two hundred feet. Knowledge does not correct anything because it is the body which contains the idea of the sun which stimulates the body. The constitution of the body constitutes and organizes the constitution and the organization of the imagination.

Spinoza anticipates Freud when he writes that drive is the essence of man, and that desire is nothing else but drive and its awareness (Spinoza, 1677/2002, p. 185). Spinoza adds that he sees no difference "[...] between the human impulse and desire, because whether or not a person is aware of his desire the desire remains the same” (Spinoza, 1677/2002, p. 54). Affect alone is barely the excitation of the body which sustains, increases, or decreases the potential for action. As sadness diminishes or inhibits the power for action, joy increases our ability to act. "Joy and sorrow, and hence the affects composed from these and derivative are passive states [...]" (Spinoza, 1677/2002, p. 87). Let us note, however, that passivity does not entail indifference. On the contrary, this passivity means permanent infection by affects and restless fidgeting of multiple desires which are continuously excited by out-of-tune instrument delivering yet new sounds, including howling, snarling, and giggles—all thanks to random indifference of nature.

\section{Contrary Affect}

Let us, therefore, return to the question of affect and the question of idea (representation). According to Spinoza, what forms certain state (constitutio) of the affected body are affection-images or otherwise complexes of affections-images and affects-feelings producing each time a state different from the previous one in that it is characterized by higher or lower perfection. Ideas-affections, therefore, in their duration are subject to modulation of intensity. "The series defining the duration or change are referred to as 'affects' or affections (affectus)" (Deleuze, 1988b, p. 80). As a general rule, the affection (affectio) refers to the body, whereas the affect (affectus) to the mind. The affection, therefore, concerns merely the existence of a given state of affection of the body, whereas the affect (affectus) refers to multiple passages (changes) between one state and another (Deleuze, 1988b, pp. 96-100). Affections are thus akin to edges (curbs), whereas affects are akin to bridges (folds).

Ideas represent certain things or states of things, whereas feelings involve the passages in between those states of things which come at a variable intensity corresponding to the variation of states. Under the natural conditions of perception, the ideas represent what happens to our body and the effects of other bodies on ours, 
and therefore, they represent a concoction of the two. Such ideas indeed are images. Images are corporeal affections themselves with traces external bodies' influence. As such, ideas always comprise the idea of image and affection, and reflect the presence of external bodies. The manner in which these ideas are connected is primarily in accordance with the order provided by memory or habit. It follows that the order of memory is the product of random encounters between bodies.

As long as our feelings are the effect of random affection, the content of these is the resultant of the nature of affection, on the one hand, and the hazy images blended in our state on the other. Spinoza refers to these affects as a "passive state", that is the instance of sheer reactivity, while Freud calls them façade or pathogenic formations (themes) which should be dissolved. Spinoza seems to believe that only the idea of the internally induced affectio, or, in other words, self-excitement-albeit indicating the internal consistency of our constitution with that of other bodies-may produce affects featuring instantaneous activity. It is the instance which Spinoza refers to as "active state".

Such a constitution affects is accompanied by a special intellectual (analytical) apparatus. Thinking based on nominal definitions is exercised only in abstraction which is parasitic on external descriptions and employs definitions, such as that of a circle; the set of all points in a plane that are equidistant from a given point called the centre of the circle. In contrast, real definitions are of genetic character: They indicate the cause for the thing or its genetic components, e.g., circle is movement of a line of which one end is fixed. Real definitions are not semantic postulates; they are simultaneously the explication and the implication (perception) of things. They are thus able to capture not only the characteristics of a thing, but also capture its movement. Such is the thinking which may foster active affects.

Adequate ideas constitute a regular set and cannot be disconnected from the contexture of ideas placed in the attribute of thinking. This contexture is also the order of understanding and perceiving things, a coincident expression of the order of ideas and the order of events, which altogether makes of the mind nothing but a spiritual automaton. According to Freud, Leonardo provides us with a fine example of such a spiritual automaton. A true (adequate) idea presents nothing-It is but an expression of its cause, thus delivering its genetic definition. Spiritual automaton involves silent indifference. Leonardo’s Mona Lisa represents no actual thing, such as the wife of the Florentine cloth and silk merchant Francesco del Giacondo. The sole cause and the reason for Mona Lisa's smile is the smile of Leonardo's biological mother whom our “Italian Faust” lost at the time of her death.

The author believes that it is proposition VII of Part Four of Ethics that we should find of particular pertinence in our considerations. Therein, Spinoza claims that an emotion cannot be checked or destroyed otherwise that by contrary emotion which is stronger than the earlier emotion, thereby compelling us to conclude that thinking alone does not have the power to stop affects. Thinking, in fact, is yet another affect. It is hardly surprising a statement granted that the proposition XXXI of the first part renders intellect in action not as an abstract thinking but a certain mode of thinking, different from other modi, such as desire or love (Spinoza, 1677/2002, p. 44). A desire originating in reason may arise only from the affect of joy, which, however, is not a passive state. It is an affect induced alongside the process of thinking. The affect of joy is a thought understood as a vector of action of the affect.

Spinoza states clearly and categorically: All our desires inherently arise from our nature in such a manner that they can be either understood by itself—-since they are its immediate (direct) cause—or by us as being part of nature. It is the very desires arising from our nature in such a way that they can be understood by itself that 
are the cause of adequate ideas. Other desires belong in the imaginary register, and, consequently, to inadequate ideas. Eventually, therefore, Spinoza equals the status of affect with that of idea where he stressed that "an affect which is a passion ceases to be a passion as soon as we form a clear and distinct idea of it" (Spinoza, $1677 / 2002$, p. 339) and later goes on to suggests that "there is no other power of the mind than the power of thought and of forming adequate ideas” (Spinoza, 1677/2002, p. 342).

Spinoza, in the summary of the fifth part of Ethics entitled "Of the Power of the Intellect or on Human Freedom" states that the power of the mind over the affections relies on a set of regulations and devices. First, it rests in the very knowledge of the emotions. Second, it rests in the ability to detach the emotions from the thought of their external cause which the subject always imagines confusedly. Thirdly, it rests in the matter of time in respect of which the affections related to things that we understand are considered superior to those affections that are confused. Fourth, it rests in "the number of causes whereby those affections are fostered which are related to the common properties of things" (Spinoza, 1677/2002, p. 355). Fifth, and lastly, the power of intellect over affections rests in the architecture the order of the mind, whereby the mind can arrange its emotions.

When taken literally the above postulates may stir a lot of confusion. The power over affects can be conceived otherwise than through reference to knowledge, separation of affect and thought, time of affection, the number of stimuli nor the way they link. Spinoza's theory of affects compels us to think: (1) thought as emotion; (2) expression as causality; (3) transmission speed as the function of the throughput of the link; and (4) priming as the persistent advantage of thought over affect. Human brain even without organs is still not blank, nor is a phantom of the brain or a spiritual automaton. Instead, it ought to be thought of as possessing unlimited computational power. Such a brain laughs first at a joke. The author cannot imagine the sound of his laughter. Perhaps the closest to it would be hissing.

\section{Conatus (Beyond Death Drive)}

Deleuze rightly discerns at least three ways of reading Spinoza's central concept of conatus (power and striving). First, conatus can be understood as commitment to persevere in existing, sustaining life, and circularity of being. This is a mechanical definition of conatus, which makes of it a tool of death drive. From Hobbes to Freud, both philosophy of life and political philosophy were philosophies of self-preservation, i.e., sustaining life. Yet, paradoxically, these philosophies were becoming philosophies of death.

When today Rosi Braidotti speaks on behalf of the subject founded on plenitude rather than scarcity and defends the idea of sustainability (Braidotti, 2013), this may be construed as confusing conatus understood as perseverance (survival) with conatus understood as composing and adding. In a second determination, the conatus is a pseudo-dialectic force opposing any disturbances and threats and as such it negates, defends, avoids, wanders, cheats, and deceits. Hegel, in his dialectic of master and servant, gives perhaps the first outlook of this strange logic of deception and deferring death through deception, whereby life gets dispersed in a multitude of petty deaths and their simulations. It is in this sense that we may see in the conatus a set of defence mechanisms and a power to create façade formations. Finally, in a third determination, the conatus is a dynamic force aimed at enhancing the power of understanding; as such it involves the freedom to react and create compositions (collectives). In this final determination, conatus stands for reason, here understood as a power to select and organize. 
Let us here ponder on the question of freedom to respond and how it relates to feeling or sensing things. What, in fact, is a sensation? In Bergsonism, Deleuze (1988a) defined is as "the operation of contracting trillions of vibrations onto a receptive surface” (p. 74). In his further writings, notably in The Fold: Leibniz and the Baroque, Deleuze (1993) repeated this thought, stating that: “[...] chaos would be a universal giddiness, the sum of all possible perceptions being infinitesimal or infinitely minute; but the screen would extract differentials that could be integrated in ordered perceptions” (p. 179). The closest image of sensing things that we may get is that of a carousel, with all dizziness, fainting, sleep inertia, a multitude of impressions understood as forces. In this image of feeling consists in a trillion of minute perceptions, vibrations, glows, flashes, irrelevant signals, and noises which can be assigned to no perceptible shape (Gestalt). Deleuze monotonously repeats that what captures the semblance of sensing things is neither form nor function, neither structure nor figure but brushwork and texture.

Personally, the author does not share Deleuze's belief in the possibility of deriving all three formulas of conatus from one affirmative concept of life. Sadly, it is far from being true. It is only in conatus understood as striving to amplify the power to act and experience joyful and non-passive affects where we find affirmative power (Deleuze, 1988b, p. 120). Pseudo-dialectic concept of conatus seems to suggest that affects-affections (affectus) are nothing other than its pseudo-figurations that arise when conatus is determined to do something in response to external stimulation (affectio) which is accidental to the body, and the nature and strength of which the body does not understand. Finally, conatus understood as pure duration is simply a struggle for survival, is a pure death drive (Freud, 1920/1968), maniacally struggling to preserve its existence.

Reactive forces decompose and separate the active power from its potential, confounding, and conflicting the power and consent. Active powers not only associate, they also acquiesce to being influenced. Sensitivity understood as power involves subjecting to influence and being free from long-term memory (Deleuze, 2006). If, however, the capacity to be affected is to be perceived as the proper (real) and not just imaginative power to act, then it can be effected only by active affection, i.e., free short-term memory, which entails that the freedom from infiltrations, i.e., the elimination and final dissolution of affects-images, liberation from unnecessary growths in the body through the application of the method per via di levare, is in fact equal to giving consent to the state of minute deaths. In destroying these infiltrations, we also destroy our egos. Perhaps the state following such a liberation (self-destruction) is not that of general indifference, but a friendly and sometimes gallows humour. After all, is thinking not designed to give account of the chaos, in which the brain as the cognitive subject is immersed? Does the consent to such self-destruction not require gallows humour in the first place?

\section{Conclusions (Cymbals)}

It was in the early work on the philosophy of David Hume, where Deleuze argued that the subject of empiricism is never given but rather made of the data and constituted by the rules made of data and founded on a fantasy that goes beyond what is given (Deleuze, 1991). The subject of empiricism is resonance, yet it is not the resonance produced by wind instruments as long as the players are blowing but by stringed instruments, where after each stroke the strings produce vibrations and where the sound disappears in duration, that is, where the disappearance of vibrations spans in time. It is this kind of resonance where the "principles of emotions" need to synchronize (align) with the rules of association. The only instrument capable of such a "detuned harmonic" is a percussion section, and more specifically—cymbals. 
The mind is a percussion section; it is a constellation (apparatus and organ]) devoid of organization. A percussion section is a musical instrument in the state of madness. The image of brain lobes is that of cymbals.

Madness-Deleuze writes-is human nature related to the mind, just as good sense is the mind related to human nature; each one is the reverse of the other. This is the reason why we must reach the depths of madness and solitude in order to find a passage to good sense (Deleuze, 1991, p. 84).

When fiction of representation becomes the principle, then thinking ceases to reflect and correct. Reason is a fantasy transmuted into nature. Thinking manifests itself as madness because originally it is the madness of a percussion section. An orderly system can be derived just as easily from the folds of abdomen as from the texture of the brain or vibrations produced by cymbals. Thinking, indeed, is a dangerous exercise. The brain understood as a defence against the chaos of the world is unable to innovatively respond to its own chaos. Brain-cymbals are immersed in great ignorance, i.e., general indifference. The brain does not distinguish between affections of the world and self-excitement.

Such was Freud's premonition from the very onset. Freud constantly revolves around psychosis, yet he never approaches it close enough. It is perhaps a mistake to think of the nervous system in terms of registers, representations, etc., i.e., to understand it as the organ designed to form representations. Perhaps the brain does not represent anything, but instead instantly sketches out the whole multitude and multiplicity of all possible actions. Considering "humour" of the brain, we should challenge the question of representation formed by an anvil experiencing a growing number of hammer blows. Would the chaos of consecutive strokes be applied to the canvas of orderly representations thereby producing infiltrations? Or would this spontaneous hammering bring a harmony from melody or, yet, a melody from harmony (Deleuze, 1993)? Anvil is not an indifferent instrument even though it is by no means a sensitivity screen is neither a telephone switchboard even nor a telephone receiver.

Perhaps this concerto for anvil allows us to hear a reversed-laughter or, rather, a bizzare-sounding crescendo of murderers. Myself, I am not sure whether or not this laughter belongs to a victim (Theweleit, 2015). For Bergson, laughter is caused by a shift from what is living to what is dead, i.e., the degradation of what is living to the state of mechanical deadness and mechanical repetition. "A really living life should never repeat itself”, states Bergson (Bergson, 1999/1911). The living of brain-cymbals is repeated only in the mantle of folds of the consecutive cymbals-lobes as they are vibrating along the stimulation of a spiritual automaton.

\section{References}

Bergson, H. (1999/1911). Laughter: An essay on the meaning of the comic. (C. Brereton and F. Rothwell, Trans.). Los Angeles: Green Integer.

Braidotti, R. (2013). The posthuman. Cambridge: Polity Press.

Deleuze, G. (1988a). Bergsonism. (H. Tomlinson and B. Habberjam, Trans.). New York: Zone Books.

Deleuze, G. (1988b). Spinoza: Practical philosophy. (R. Hurley, Trans.). San Francisco: City Lights Books.

Deleuze, G. (1990). Expressionism in philosophy: Spinoza. (M. Joughin, Trans.). New York: Zone Books.

Deleuze, G. (1991). Empiricism and subjectivity. (C. Boundas, Trans.). New York: Columbia University Press.

Deleuze, G. (1993). The fold: Leibniz and the baroque. (T. Conley, Trans.). London: Athlone Press.

Deleuze, G. (2006), Nietzsche and philosophy. (H. Tomlinson and M. Hardt, Trans.). Columbia University Press.

Deleuze, G., \& Guattari, F. (1994). What is philosophy? (H. Tomlinson and G. Burchell, Trans.). New York: Columbia University Press.

Freud, S. (1900/1957). The interpretation of dreams. In J. Strachey (Ed.), The standard edition of the complete psychological works of Sigmund Freud (Volume IV). London: Hogarth Press. 
Freud, S. (1904/1905). On psychotherapy. The Standard Edition of the Complete Psychological Works of Sigmund Freud, Volume VII (1901-1905). Retrieved from http://www.bgsp.edu/?mdocs-file=6774

Freud, S. (1905). Jokes and their relation to the unconscious. In J. Strachey et al. (Ed.), The standard edition of the complete works of Sigmund Freud (Volume XIII, pp. 1953-1974). London: Hogarth Press.

Freud, S. (1910). Concerning “wild” psycho-analysis. In J. Strachey (Ed.), The standard edition of the complete psychological works of Sigmund Freud (Volume XI). London: Hogarth Press.

Freud, S. (1910/1957). Leonardo da Vinci. A psychosexual study of an infantile reminiscence. In J. Strachey (Ed.), The standard edition of the complete psychological works of Sigmund Freud (Volume XI, A. Brill, Trans.). London: Hogarth Press.

Freud, S. (1912). The dynamics of transference. The Standard Edition of the Complete Psychological Works of Sigmund Freud, Volume XII (1911-1913). Retrieved from https://chicagoanalysis.org/system/files/readings/Freud,\%20S.\%20\%5B1912\%5D\%20-\%20The\%20Dynamics\%20of\%20Tra nsference.pdf

Freud, S. (1915). Observations on transference-love (Further recommendations on the technique of psycho-analysis III). The Standard Edition of the Complete Psychological Works of Sigmund Freud, Volume XII (1911-1913). Retrieved from https://pdfs.semanticscholar.org/54f1/96b0068b203fc95ad633563b546d076c3e19.pdf

Freud, S. (1920/1968). Beyond the pleasure principle. In J. Strachey (Ed. and Trans.), The standard edition of the complete psychological works of Sigmund Freud (Volume XVIII). London: Hogarth.

Freud, S. (1939/1957). Moses and monotheism. In J. Strachey (Ed. and Trans.), The standard edition of the complete psychological works of Sigmund Freud (Volume XXIII). London: Hogarth.

Hurley, M. M., Dennett, D. C., \& Adams, R. B. (2013). Inside jokes: Using humor to reverse-engineer the mind. Cambridge: MIT Press.

Spinoza, B. (1670/1951). A theologico-political treatise/a political treatise. (R. H. M. Elwes, Trans.). New York: Dover Publications.

Spinoza, B. (1677/2002). Ethics. In M. L. Morgan (Ed.), Spinoza: Complete works (S. Shirley, Trans.). Indianapolis: Hackett Publishing.

Theweleit, K. (2015). Das Lachen der Täter: Breivik u.a.. Psychogramm der Tötungslust (The laughter of killers: Beivik et al. A psychogram of killing for pleasure). (Salzburg, Österreich: Residenz Verlag. 